\title{
The Stop Signal Revised: Immature Cerebellar Granule Neurons in the External Germinal Layer Arrest Pontine Mossy Fiber Growth
}

\author{
M. Chiara Manzini, ${ }^{1}$ M. Stanton Ward, ${ }^{2}$ Qin Zhang, ${ }^{1}$ Michael D. Lieberman, ${ }^{2}$ and Carol A. Mason ${ }^{1,2}$ \\ ${ }^{1}$ Center for Neurobiology and Behavior, ${ }^{2}$ Department of Pathology and Cell Biology, College of Physicians and Surgeons, Columbia University, New York, \\ New York 10032
}

During the formation of neuronal circuits, afferent axons often enter target regions before their target cells are mature and then make temporary contacts with nonspecific targets before forming synapses on specific target cells. The regulation of these different steps of afferent-target interactions is poorly understood.

The cerebellum is a good model for addressing these aspects, because cerebellar development is well defined and identified neurons in the circuitry can be purified and combined in vitro. Previous reports from our laboratory showed that cultured granule neurons specifically arrest the extension of their pontine mossy fiber afferents, leading us to propose that granule cells arrested growth of their afferents as a prelude to synaptogenesis. However, we knew little about the differentiation state of the cultured granule cells that mediate afferent arrest.

In this study, we better define the purified granule cell fraction by marker expression and morphology, and demonstrate that only freshly plated granule cells in the precursor and premigratory state arrest mossy fiber outgrowth. Mature granule cells, in contrast, support extension, defasciculation, and synapse formation, as in vivo. In addition, axonal tracing in vivo during the first postnatal week indicates that immature mossy fibers extend into the Purkinje cell layer but never into the external germinal layer (EGL), where precursors of granule cell targets reside. We found that the stop-growing signals are dependent on heparin-binding factors, and we propose that such signals in the EGL restrict the extension of mossy fiber afferents and prevent invasion of proliferative regions.

Key words: development; cerebellum; pons; granule cell; axon outgrowth; synaptogenesis

\section{Introduction}

The mechanisms of axon pathfinding during neuronal circuit formation have been extensively explored (Tessier-Lavigne and Goodman, 1996; Yu and Bargmann, 2001), but the regulation of afferent extension within target regions is poorly understood. Afferent growth cones must encounter molecular cues, produced by cells in the target region to modulate growth, prevent inappropriate contacts, and mediate synaptogenesis.

The relationships between rodent cerebellar granule neurons and their pontine afferents, the mossy fibers, comprise an ideal model for afferent-target interactions (Ramon y Cajal, 1911; Mason and Gregory, 1984; Baird et al., 1992a,b; Scheiffele et al., 2000; Umemori et al., 2004). Components of the cerebellar circuitry

\footnotetext{
Received Nov. 9, 2005; revised April 21, 2006; accepted April 26, 2006.

This work was supported by National Institutes of Health Grants NS15961 and EY015290 (C.A.M.) and Medical Scientist Training Program Training Grant T32 GM07367 (M.S.W.). We thank Peter Scheiffele, Anna Kalinovsky, Scott Williams, Mary Morrison, Takeshi Sakurai, and Amy Chung for discussion and comments on this manuscript and Hranush Melikyan and Rich Blazeski for invaluable technical help.

Correspondence should be addressed to Dr. Carol A. Mason, Department of Pathology, 14-509 P\&S Building, Columbia University, College of Physicians and Surgeons, 630 West 168th Street, New York, NY 10032. E-mail: cam4@columbia.edu.

Q. Zhang's present address: SKI Research Computing, Memorial Sloan-Kettering Cancer Center, 1275 York Avenue, New York, NY 10021.

DOI:10.1523/JNEUROSCI.4815-05.2006

Copyright $\odot 2006$ Society for Neuroscience $\quad$ 0270-6474/06/266040-12\$15.00/0
}

and their differentiation are well defined (Hatten and Heintz, 1995; Goldowitz and Hamre, 1998; Wang and Zoghbi, 2001), and the ability to purify identified cell types allows tests of afferenttarget interactions in a coculture setting (Hatten et al., 1998).

Granule neurons undergo proliferation postnatally under the pial surface, within the external germinal layer (EGL). Subsequently, granule cell axons extend beneath the EGL and their cell bodies migrate through the Purkinje cell layer (PCL) to settle in the internal granule layer (IGL), where they receive synapses from mossy fiber afferents. Single fiber tracing of cerebellar afferents has shown that developing mossy fibers form en passant synapses on mature IGL cells and extend into the PCL, where they also relate to immature Purkinje cells and migrating granule cells (Mason and Gregory, 1984; Mason, 1986; Arsenio Nunes et al., 1988; Liesi et al., 2003). Thus, mossy fiber outgrowth may be regulated at several levels, involving interactions with immature targets cells and inappropriate targets, such as Purkinje cells.

Previous work from our laboratory revealed that purified granule cells in culture inhibit pontine axon outgrowth. We interpreted this interaction to reflect arrest of afferent extension by the target cell as a prelude to synaptogenesis (Baird et al., 1992a; Mason et al., 1997). However, other evidence indicated that at the time of plating, purified granule neurons are composed of an immature EGL-like population (Raetzman and Siegel, 1999; 
Solecki et al., 2001; Diaz et al., 2002), suggesting that mossy fibers in our model were arrested by immature rather than mature granule cells.

Here, by combining in vivo and in vitro approaches, we asked whether immature or mature granule cells inhibit mossy fiber outgrowth. In vivo tracing of pontine mossy fibers showed that postnatally, pontine axons grow into the PCL, but never into the EGL. However, when granule cells are absent, as in the meander tail mutant cerebellum (Ross et al., 1990), mossy afferents grow to and along the pial surface. When we compared the effect of EGL- or IGL-like granule neurons on mossy fiber outgrowth in culture, we observed that immature cells strongly inhibit mossy fiber outgrowth, whereas differentiated neurons support growth and synaptogenesis, as in the IGL in vivo (Mason and Gregory, 1984). Proliferative outer-EGL neurons are the strongest source of the inhibitory activity, which appears to be dependent on a heparin-binding component.

\section{Materials and Methods}

Animals. Experiments were performed with C57BL/6J mice, green fluorescent protein (GFP) transgenic mice expressing GFP under a $\beta$-actin promoter (Okabe et al., 1997) on a C57BL/6J background and meander tail (mea/mea) mice (Ross et al., 1990). These animals were derived from a timed pregnancy breeding colony under our direction at Columbia University, with the day a plug was found considered embryonic day 1 (E1) and the day the pups were born designated as postnatal day 0 (P0). Cerebellar granule neurons were harvested from P5 pups and pontine explants were dissected from P0 animals.

1,1'-Dioctadecyl-3,3,3',3'-tetraindocarbocyanine perchlorate injections and photoconversion. $\mathrm{P} 0-\mathrm{P} 6$ pups were anesthetized with a mixture of ketamine and xylazine $(50 / 10 \mathrm{mg} / \mathrm{kg}$ ) and perfused transcardially with $4 \%$ paraformaldehyde in $0.1 \mathrm{M}$ phosphate buffer. Pontine mossy fibers were labeled with $1,1^{\prime}$-dioctadecyl-3,3,3',3'-tetraindocarbocyanine perchlorate (DiI) (Invitrogen, San Diego, CA) following previously described procedures (Godement et al., 1987; Marcus et al., 1995). Briefly, DiI crystals were suspended in Triton X-100 (Sigma, St. Louis, MO), loaded in a micropipette and injected by gently puncturing the pontine nucleus. Brains were stored in $0.1 \mathrm{~m}$ phosphate buffer in the dark at room temperature for 4-8 weeks, depending on age. For analysis, 70-80 $\mu \mathrm{m}$ vibratome sections were cut and sections with good axonal labeling as well as restricted pontine injections were photoconverted. Sections were placed in a depression slide filled with $0.1 \mathrm{M}$ Tris buffer, $\mathrm{pH} 8.2$, and kept in immersion for a few minutes. After withdrawing Tris buffer, a few drops of diaminobenzidine (DAB) solution $(1.5 \mathrm{mg} / \mathrm{ml}$ in Tris buffer) were added to cover the section. The desired area was illuminated at the wavelength for rhodamine. Optimal results were obtained with a Nikon (Tokyo, Japan) $10 \times$ or $20 \times$ Neofluor objective and a $100 \mathrm{~W}$ mercury lamp, on a Nikon Optiphot microscope. The average reaction time was $20-30 \min (10 \times$ objective) or $10-15 \min (20 \times$ objective). Brains with good mossy fiber labeling were analyzed for each age in wild-type and meander tail mice: wild-type brains, $n=3, \mathrm{E} 19 ; n=8, \mathrm{P} 0 ; n=5$, P4; and $n=3$, P6; meander tail brains, $n=7$, P4; and $n=7$, P6.

To locate Purkinje cells, some photoconverted sections were immunostained with an anti-calbindin- $\mathrm{D}_{28 \mathrm{~K}}(\mathrm{CaBP})$ antibody (1:1000; SWant, Bellinzona, Switzerland) using a procedure similar to that described by Marcus et al. (1995). After photoconversion, sections were preblocked in $10 \%$ normal goat serum with $0.05 \%$ Triton X-100 in $0.1 \mathrm{M}$ phosphate buffer, $\mathrm{pH}$ 7.4, for $1 \mathrm{~h}$ at room temperature, followed by an overnight incubation with the CaBP antibody in $1 \%$ serum-phosphate buffer with $0.05 \%$ Triton X-100 at $4^{\circ} \mathrm{C}$. Secondary staining was performed with a peroxidase-conjugated goat anti-rabbit IgG $(1: 100)$ for $1 \mathrm{~h}$ at room temperature, and then detected with DAB (10 $\mu \mathrm{g}$ of DAB, $5 \mu \mathrm{l}$ of $8 \% \mathrm{NiCl}_{2}$, and $4 \mu \mathrm{l}$ of $3 \% \mathrm{H}_{2} \mathrm{O}_{2}$ in $1 \mathrm{ml}$ of phosphate buffer) for $10 \mathrm{~min}$. In some cases, $\mathrm{CaBP}$ staining was intensified by $\mathrm{CoCl}_{2}$ treatment. Photoconverted and double-stained sections were mounted on gelatin-coated slides and allowed to dry. After dehydration in a series of ethanol and clearing in xylene, sections were coverslipped with Permount.
Culture media. Culture medium was composed of Eagle's basal medium with Earle's salts (BME) (Invitrogen ) supplemented with glutamine (2 mM; Invitrogen), glucose $(0.5 \%)$, and penicillin/streptomycin $(20 \mathrm{U} / \mu \mathrm{l}$; Invitrogen ). All cultures were kept in serum-free medium, a medium of defined composition that yields comparable neuronal survival as the traditionally used serum-containing medium (Gasser and Hatten, 1990). Serum-free medium contained the following supplements: insulin $(5 \mu \mathrm{g} / \mathrm{ml})$, transferrin $(5 \mu \mathrm{g} / \mathrm{ml})$, selenite $(5 \mathrm{ng} / \mathrm{ml})$, and bovine serum albumin $(10 \mathrm{mg} / \mathrm{ml})$, all from Sigma.

Purification of cerebellar granule neurons. Materials and methods for isolation and purification of granule neurons were as previously described (Hatten, 1985; Baird et al., 1992a; Hatten et al., 1998). Briefly, cerebella dissected from mouse brains on P5 were dissociated to a singlecell suspension and separated into high- and low-density fractions on a 35-60\% Percoll (Sigma) step gradient. Purified granule neurons were obtained from the high-density fraction and further purified by two serial preplating steps in tissue culture plastic Petri dishes coated with poly-D-lysine (100 $\mu \mathrm{g} / \mathrm{ml}$; Specialty Media, Phillipsburg, NJ) to remove non-neuronal cells. Granule neurons were resuspended in serum-free medium and plated at a density of $2.5 \times 10^{5} \mathrm{cells} / \mathrm{cm}^{2}$ on glass coverslips (VWR Scientific, West Chester, PA) or in 16-well LabTek chamber slides (Nunc, Naperville, IL) coated with poly-L-ornithine (100 $\mu \mathrm{g} / \mathrm{ml}$; Sigma) and mouse laminin $(20 \mu \mathrm{g} / \mathrm{ml}$; Invitrogen $)$. Cells were kept up to $14 \mathrm{~d}$ in culture changing the culture medium every $3-4 \mathrm{~d}$ and fixed at set time points for immunocytochemistry to monitor differentiation. For cocultures, cells were plated as described below.

Pontine explant-granule cell cocultures. Pontine explants for coculture were prepared as described (Baird et al., 1992a; Hatten et al., 1998). Briefly, the basilar pontine nuclei were excised from the base of the brainstem of P0 mouse brains in ice-cold Tyrode's calcium/magnesium-free PBS. The excised pontine nuclei were transferred into serum-free medium and cut into microexplants $\sim 200 \mu \mathrm{m}$ in diameter. Between five and eight microexplants were plated in $100-250 \mu \mathrm{l}$ of serum-free medium on microwell coverslip dishes (MatTek, Ashland, MA). The coverslips were coated with poly-L-ornithine $(100 \mu \mathrm{g} / \mathrm{ml}$; Sigma) and mouse laminin $(20 \mu \mathrm{g} / \mathrm{ml}$; Invitrogen ). Granule neurons were plated at a density of $2.5-3 \times 10^{5}$ cells $/ \mathrm{cm}^{2}$ either $3 \mathrm{~h} \mathrm{[0} \mathrm{d} \mathrm{in} \mathrm{vitro} \mathrm{(div)} \mathrm{cells]} \mathrm{or} 4 \mathrm{~d}(4$ div cells) before addition of explants.

In half-dish cocultures, granule cells were allowed to attach on only one-half of the dish by covering the other half with a semidisk of sterile Whatman (Maidstone, UK) paper cut to fit the well and the paper held in place with a small metal rod (a trimmed dissecting pin). When granule cells were plated, one-half of the cells sit on the poly-L-ornithine/laminin substrate, while the other one-half attach to the paper. After $2-3 \mathrm{~h}$, the paper was removed leaving one-half of the dish empty. Explants could then be plated in the empty one-half and aligned in a row $200-300 \mu \mathrm{m}$ from the granule cell boundary (see Fig. $4 A$ ).

For heparin treatments, heparin $(10 \mu \mathrm{g} / \mathrm{ml}$; Sigma $)$ was added in the culture medium the morning after plating pontine explants on a full dish of granule cells, as addition of heparin at plating interfered with explant attachment. Cocultures were fixed after $24 \mathrm{~h}$ of heparin treatment.

Pontine explant cultures on granule cell membranes. For cocultures on granule cell membranes, membranes were prepared by scraping monolayers of granule cells in $4^{\circ} \mathrm{C}$ PBS with protease inhibitors (Complete Protease Inhibitor Cocktail; Roche, Basel, Switzerland) and pelleting out the nuclear fraction. Plasma membranes were purified via Percoll density gradient centrifugation followed by sucrose flotation to separate plasma membrane and lysosomal fractions. Pontine explants were plated on uniform membrane carpets prepared on poly-L-ornithine/laminin substrate. For cocultures with freeze-fixed granule cells, granule cell cultures were fixed before pontine explants were plated by placing the culture dish on a metal block immersed in liquid nitrogen, and methanol was added to the cells to substitute for cellular water and preserve morphology.

A2B5 and transient axonal glycoprotein-1 immunopanning. P5 mouse cerebellar granule cells were isolated by Percoll density gradient centrifugation as described previously (Baird et al., 1992a) (see above), except that papain $(10 \mathrm{U} / \mathrm{ml}$; Worthington, Freehold, NJ) was used for cerebellar dissociation instead of trypsin. Immunopanning plates were prepared by absorbing a rabbit anti-mouse IgM antibody (MP Biomedicals, Irvine, 
CA) diluted in $50 \mathrm{~mm}$ Tris, $\mathrm{pH} 9.5$, to polystyrene plates overnight at $4^{\circ} \mathrm{C}$. After washing with PBS, anti-transient axonal glycoprotein-1 (TAG-1) (1:4; clone 4D7; generous gift from Dr. Tom Jessell, Columbia University, New York, NY) and A2B5 (1:2; Chemicon, Temecula, CA) monoclonal antibodies were added to the plates and incubated for $3 \mathrm{~h}$ at $37^{\circ} \mathrm{C}$. To decrease nonspecific binding, immunopanning plates were incubated with BME (Invitrogen ) containing 10\% horse serum (Invitrogen) and cells were blocked with rabbit anti-mouse IgM (MP Biomedicals) for 30 min at $37^{\circ} \mathrm{C}$. Cells were bound to immunopanning plates with three sequential $45 \mathrm{~min}$ incubations. TAG-1-positive cells were removed first by binding to the TAG-1 immunopanning dish and other cells were collected for subsequent panning. Because $02 \mathrm{~A}$ glial precursors also express $\mathrm{A} 2 \mathrm{~B} 5$, an intermediate panning step was added to remove them using NG2, a chondroitin sulfate proteoglycan present only in 02A precursors (Levine and Stallcup, 1987). TAG-1-negative cells were incubated with free NG2 antibody (1:10; Chemicon) before being added to plates coated with anti-mouse IgG (MP Biomedicals). Finally, TAG-1negative, NG2-negative cells were bound to A2B5 immunopanning plates to select for granule neuron precursors. Cells binding to TAG-1 and A2B5 plates were removed using trypsin-EDTA (Invitrogen ), resuspended in serum-free medium, and plated on glass coverslips (VWR) as described above.

5-Bromo-2'-deoxyuridine incorporation. To monitor proliferation during the first days in vitro, 5-bromo-2'-deoxyuridine (BrdU) $(10 \mu \mathrm{g} /$ $\mathrm{ml}$; Sigma) was added to the culture medium at $6,18,42$, or $66 \mathrm{~h}$ after plating. After a $6 \mathrm{~h}$ treatment, cells were fixed for $10 \mathrm{~min}$ with $4 \%$ paraformaldehyde and BrdU incorporation was assayed by immunostaining with an anti-BrdU antibody (Accurate Chemical and Scientific, Westbury, NY) in the presence of $500 \mathrm{U} / \mathrm{ml}$ DNaseI (Worthington) to grant access to BrdU.

Immunocytochemistry. Cells were fixed for 10-15 min with $4 \%$ paraformaldehyde at set time points. Cultures were blocked with $10 \%$ normal goat serum in PBS containing $0.05 \%$ Triton X-100 when membrane permeabilization was required. Primary antibody incubation was at $4^{\circ} \mathrm{C}$ overnight in the presence of $1 \%$ normal goat serum and $0.05 \%$ Triton $\mathrm{X}-100$, when necessary. Primary antibodies were as follows: rabbit antimouse atonal homology 1 (Math1) (generous gift from Dr. Jane Johnson, University of Texas Southwestern, Dallas, TX), mouse IgM anti-TAG-1 (generous gift from Dr. Tom Jessell), rabbit anti-zinc finger in cerebellum 2 (Zic2) (generous gift from Dr. Steve Brown, Columbia University, New York, NY), rabbit anti-myocyte enhancer factor-2 (MEF2) (Santa Cruz Biotechnology, Santa Cruz, CA), rabbit anti-synapsin I (Chemicon), and mouse IgG anti-postsynaptic density-95 (PSD-95) (ABR, Golden, CO). All secondary antibodies were from Invitrogen and incubation was performed for $2 \mathrm{~h}$ at room temperature. For quantification of marker expression, stainings were repeated on at least three independent sets of cultures.

Wisteria floribunda agglutinin staining. Granule cell cultures and pontine explant cultures were fixed in $4 \%$ paraformaldehyde at set time points. They were blocked using an avidin/biotin blocking kit (Vector Laboratories) according to the manufacturer's specifications, and incubated overnight in biotin-conjugated Wisteria floribunda agglutinin (WFA) $(2 \mu \mathrm{g} / \mathrm{ml}$; Sigma) diluted in TBS. WFA was detected using fluorescein-conjugated avidin D (Vector Laboratories).

Microscopy and data analysis. For marker and axon outgrowth analysis, images were collected on a Zeiss (Oberkochen, Germany) Axioplan 2 microscope via a black-and-white Axiocam digital camera (Zeiss).

Marker analysis. For an accurate and unbiased representation of cell distribution in the culture well, nine independent fields were photographed at fixed positions. To identify Math1-, Zic2-, and MEF2-positive cells, images were thresholded using NIH Image software at a set value for each marker. To measure TAG-1 staining density, the area of TAG-1 staining was measured after thresholding the image at a set value and dividing by the number of cells present in the field. For all markers, the total number of cells was determined by counting either GFP- or Hoechst 33258- (Invitrogen) positive cells.

Coculture analysis. Images were taken of axons in each of the four quadrants of outgrowth. The distance from the body of the explant to the point at which $90 \%$ of the growth cones were located was measured for each quadrant using Openlab image analysis software (Improvision, Boston, MA), and all four quadrants were averaged for each explant. Outgrowth on cultured granule neurons was compared with growth on a laminin substrate. In Results, " $n=$ ” represents the number of explants and " $N=$ " represents the number of independent experiments.

\section{Results}

In vivo, pontine afferents grow toward but not within the external granule cell layer

During the first two postnatal weeks, immature cerebellar afferents extend into the developing cerebellar cortex (Mason and Gregory, 1984; Mason, 1986). Many axons, termed combination fibers, form presynaptic specializations characteristic of both mossy fibers, with large mossy fiber rosettes in the IGL, and climbing fibers, in the form of fine filopodial branches bearing small boutons that reach up to Purkinje cell bodies in the PCL. The specific origin of the combination axons, and thus whether they should be considered mossy or climbing fibers, was not known, because the axons were labeled in fiber tracts, not in the brainstem nuclei where the cell bodies are situated. In addition, the extent to which mossy fibers interacted with immature granule neurons in the EGL was not noted.

To determine the interactions of developing mossy fibers with immature granule cells in the EGL, we analyzed the time course of pontine afferent innervation, from embryonic ages to the end of the first postnatal week. Pontine projections were labeled by injecting the lipophilic dye DiI into the pontine nuclei of fixed mouse brains, and in parallel, Purkinje cells were revealed by immunostaining for calbindin ( $\mathrm{CaBP})$, a calcium binding protein that is found throughout the Purkinje cell cytoplasm (Jande et al., 1981). Between E16 and E18, pontine fibers begin to splay off of the medial cerebellar peduncle, positioned laterally and rostrally, and enter the cerebellar cortex. At this age, pontine mossy fiber growth cones are positioned in the region of the future IGL, in the developing deep nuclei, and are never seen in the developing EGL (data not shown). By E19, more pontine mossy fibers project to the cortical regions and many extend into the multicellular Purkinje cell aggregations below the EGL (Fig. 1A). A few fibers are seen to exit the main tract and to reach up to the developing EGL, but not to enter the EGL (Fig. $1 B$ ).

By P0, the folia of the cerebellum begin to form, becoming more defined as the cerebellum increases in size during the first postnatal week. At P4, Purkinje cells are aligned in a double- or single-cell layer, and above their cell bodies and developing dendrites, the EGL is approximately five cells in depth. At this age, the first granule neurons are starting to settle in the IGL after migrating past the PCL (Altman and Bayer, 1997). Mossy fibers appear to fill each folium, and the majority of mossy fiber growth cones is restricted within the IGL immediately below and around the Purkinje cell bodies, as shown previously (Mason and Gregory, 1984). However, at P6, many labeled pontine fibers were seen extending up through the Purkinje cell bodies to the developing molecular layer (Fig. $1 C-E$ ). Most growth cones on these fibers were small, and although some were observed touching the underside of the EGL, they were never seen to invade the EGL (Fig. 1D).

We asked whether in the absence of an EGL, mossy fibers would grow past the Purkinje cells to the pial surface. As previously described (Ross et al., 1990; Eisenman and Arlinghaus, 1991; Hamre and Goldowitz, 1997), the cerebellum of the meander tail mouse mutant displays a range of granule cell death from folium VI rostrally, such that at the rostral-most folium I, there is 

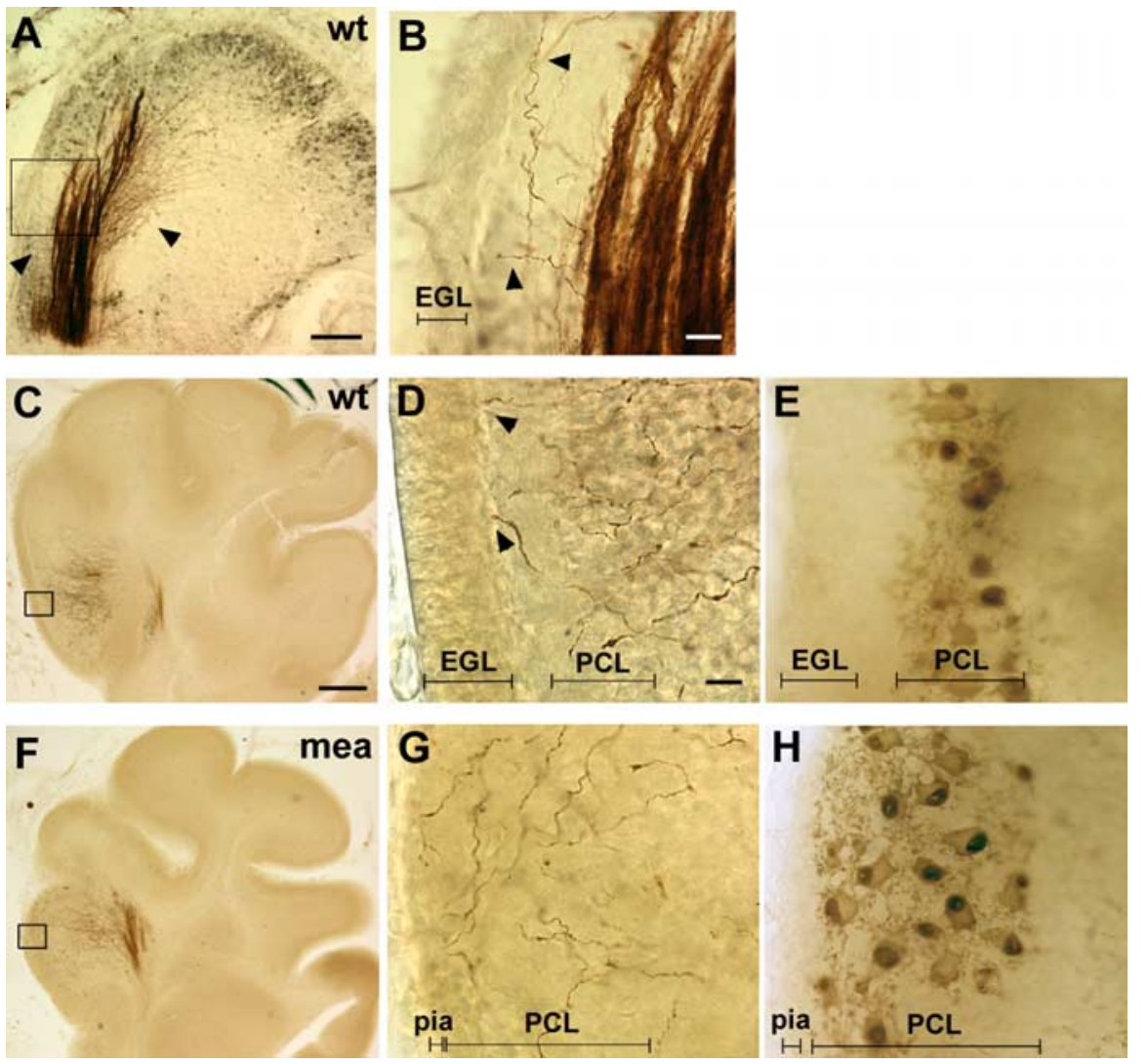

Figure 1. Developing mossy fibers extend up to the border of the EGL. Single-fiber labeling of mossy fibers by Dil insertion in the pontine nuclei is shown. After Dil photoconversion, mossy fibers appear reddish brown. Purkinje cells are visible in a darker brown or gray color in $A, E$, and $\boldsymbol{H} . \boldsymbol{A}, \boldsymbol{B}, \mathrm{E}$ 19. At low magnification $(\boldsymbol{A})$, the mossy fiber tract is seen entering the cerebellum rostrally and growing through Purkinje cell aggregates (dark gray after $\mathrm{CoCl}_{2}$ intensification of peroxidase immunostaining). Single fibers splay off the tract both anteriorly and posteriorly (arrowheads). Scale bar, $200 \mu \mathrm{m}$. At higher magnification $(\boldsymbol{B})$, single fibers project toward and under the EGL (arrowheads). Scale bar, $20 \mu \mathrm{m}$. C $-E$, P6. Mossy fibers reach up through the Purkinje cell layer but avoid the EGL. D, Mossy fiber growth cones abut the border of the EGL (arrowheads). In $\boldsymbol{C}$ and $\boldsymbol{D}$, Purkinje cells have not been stained to ease visualization of mossy fiber terminals, but the Purkinje cell layer is visible in an adjacent section (E). wt, Wild type. $\boldsymbol{F}-\boldsymbol{H}$, In folium I in the cerebellum of the meander tail mutant mouse (mea) $(\boldsymbol{F})$, the EGL is reduced or absent, and at $\mathrm{P} 6$, mossy fibers are disorganized and extend to the pial surface $(\boldsymbol{G})$. Purkinje cells are present but are not aligned in a layer $(\boldsymbol{H})$. Scale bars: (in $\boldsymbol{C}) \boldsymbol{C}, \boldsymbol{F}, 200 \mu \mathrm{m}$; (in $\boldsymbol{D}) \boldsymbol{D}, \boldsymbol{E}, \boldsymbol{G}, \boldsymbol{H}, 20 \mu \mathrm{m}$. See Materials and Methods for the number of animals analyzed.

no EGL or even individual granule cells. Purkinje cells are present in all folia, although in the affected folia (I-VI) they are not aligned into a monolayer (Fig. $1 \mathrm{H}$ ). At P6 pontine mossy fibers, labeled with DiI in the pontine nucleus, are highly disorganized when they enter folium I, and extend beneath the pia, where the EGL would have formed (Fig. $1 F, G$ ). In the wild-type cerebellum, fibers enter folium I in a well organized tract and are restricted to the developing molecular layer (Fig. $1 C, D$ ), but in the meander tail mutants projections in the most affected (anterior) folia are completely disorganized (Fig. $1 F, G$ ). Mossy fiber projections into the dorsal folia of the meander tail cerebellum, where the EGL is present, are similar to wild type and never grow into the EGL (data not shown).

Thus, under normal circumstances, mossy fibers can grow past the emerging IGL into the PCL during the first postnatal week, but do not enter the EGL region where immature granule cells are present. However, if the EGL does not form, as in the meander tail mutant, fibers do extend to the pial surface. Together, these results imply that immature granule neurons in the EGL restrict mossy fiber growth to the layers below.
Cultured granule neurons synchronously transit from an EGL-like to an IGL-like population over the first $4 \mathrm{~d}$ in vitro

To analyze the interaction between pontine afferents and granule cells at different developmental stages and to identify whether immature granule neurons arrest mossy fiber growth, we used a granule cellpontine explant coculture system. When we first identified granule neurons as a source of stopping activity for mossy fibers (Baird et al., 1992a), we had no information on the composition and differentiation stage of the granule neuron cultures that were able to inhibit mossy fiber outgrowth. Because it had been proposed that only EGL cells survive the harvesting procedure (Raetzman and Siegel, 1999), we analyzed the composition of purified granule cells cultures during the first day in vitro (i.e., at the time when pontine axons first encounter granule neurons in our coculture paradigm).

Cerebellar cells were dissociated at P5 from transgenic mice expressing GFP under the $\beta$-actin promoter (Okabe et al., 1997) and purified on a Percoll gradient to obtain a $>98 \%$ pure population of granule neurons (Hatten, 1985; Hatten et al., 1998). GFP expression in all cells allowed for morphological analysis of cultured cells and clear identification of the few contaminating glia. At 1 div, cells in culture displayed a variety of morphologies that were grouped in two distinct categories: (1) cells that displayed a flat, amoeboid morphology with a large cell body, filopodial and lamellipodial protrusions from the soma, and no neurites, and (2) cells that presented the classical bipolar shape of granule neurons in culture with two thin processes exiting a small cell body (Powell et al., 1997) (see drawings in Fig. $2 \mathrm{~A}$ and examples in Fig. 2C). Approximately one-half of the cells in culture $(45.9 \pm 2.9 \%)$ displayed the amoeboid morphology and were termed "flat cells," whereas the other one-half were bipolar (Fig. 2B).

We asked whether flat cells may be immature EGL progenitors. We first determined whether flat cells are neurons by testing for expression of neuronal and glial markers. Astroglial and oligodendroglial markers, GFAP and O4, were not expressed by flat cells (data not shown), whereas all flat cells were positive for the neuronal marker $\beta$ III-tubulin (Fig. $2 C$ ). We then analyzed proliferation in the cultures by adding BrdU to the culture medium at fixed time points during the first $48 \mathrm{~h}$ in vitro. One-third of granule cells incorporated BrdU during the first $24 \mathrm{~h}$ in culture ( $30.8 \pm 5.0 \%$ at $12 \mathrm{~h} ; 34.7 \pm 4.5 \%$ at $24 \mathrm{~h}$ ), but proliferation steeply declined by the second day in culture $(17.8 \pm 3.7 \%$ at 2 div) and ended by 3 div. All BrdU-positive cells displayed a flat morphology (Fig. 2C). In addition, a subpopulation of flat cells expressed Math1, a basic helix-loop-helix transcription factor, which is expressed by granule neurons progenitors in the outer EGL (Helms and Johnson, 1998) (Fig. 3A). 
Thus, based on morphology and marker expression at 1 div, we conclude that the purified granule cells encountered by mossy fibers in our previous coculture experiments (Baird et al., 1992a,b; Zhang and Mason, 1998) represented an immature population of EGL progenitors with a mixture of proliferating and postmitotic cells.

Because these findings favored the hypothesis that the EGL inhibits mossy fiber outgrowth to exclude afferents from immature cerebellar regions, we next wanted to determine (1) whether only immature granule neurons arrested afferent outgrowth and (2) what effect more mature granule cells had on the afferents. To ask these questions, we first defined at what time in vitro granule neurons differentiated into an IGL-like population in our culture conditions. By morphological analysis, we followed the disappearance of flat cells in culture. The number of flat cells rapidly decreased from $45.9 \pm 2.9 \%$ at 1 div to $0.6 \pm 1.1 \%$ at $3 \mathrm{div}$, and no flat cells could be detected by 4 div (Figs. $2 B ; 3 A, C$, GFP panels). In parallel, the percentage of bipolar cells increased, reaching $100 \%$ at 4 div. Because the total number of cells present in the culture remained the same over the first 4 div (data not shown), we assumed that all flat, proliferating progenitors differentiated into bipolar granule neurons. As mentioned above, BrdU incorporation had ceased by 3 div.

To further explore the composition of the cultures and the timing of differentiation, cells were immunostained for marker proteins associated with specific stages of granule cell development. The outer-EGL marker Math 1 was expressed in $13.7 \pm 3.6 \%$ of cells at 1 div, quickly declined to $0.3 \pm 0.3 \%$ of cells by $3 \mathrm{div}$, and disappeared by 4 div, closely following the disappearance of flat cells (Fig. $3 A, B)$. The Ig superfamily adhesion molecule, TAG-1, which is transiently present on growing granule cell axons during the early stages of neuronal migration (Stottmann and Rivas, 1998), was initially expressed on growing axons of bipolar granule cells at 1 div, peaked by 2 div covering the entire axonal surface, and declined thereafter, disappearing by $4 \mathrm{div}$ (Fig. 3C,D). As EGL and migration marker expression declined, late differentiation markers appeared. Zic2, a zinc-finger transcription factor, expressed in postmitotic granule cells (Aruga et al., 1996; Borghesani et al., 2002), was highly expressed as soon as the cells became bipolar (Fig. $3 E$ ) and expression followed the time course of flat to bipolar cell transition, from $50.0 \pm 7.1 \%$ of cells at 1 div to $94.3 \pm$ $0.3 \%$ at $4 \mathrm{div}$ (Fig. $3 \mathrm{~F}$ ). Zic2 expression persisted in the nuclei of all differentiated granule neurons up to $14 \mathrm{div}$, the latest times in vitro tested (data not shown). Another marker for more differentiated neurons, MEF2, a MADS family transcription factor (Lyons et al., 1995; Mao et al., 1999), appeared in bipolar granule cells later than Zic2, reached a plateau between 4 and 7 div $(70.0 \pm 2.0 \%$ at $4 \mathrm{div} ; 74.6 \pm 4.6 \%$ at $7 \mathrm{div}$ ) (Fig. $3 G, H)$, and persisted at all time points tested after 7 div.

Thus, as determined by morphology, proliferation, and differ-
B
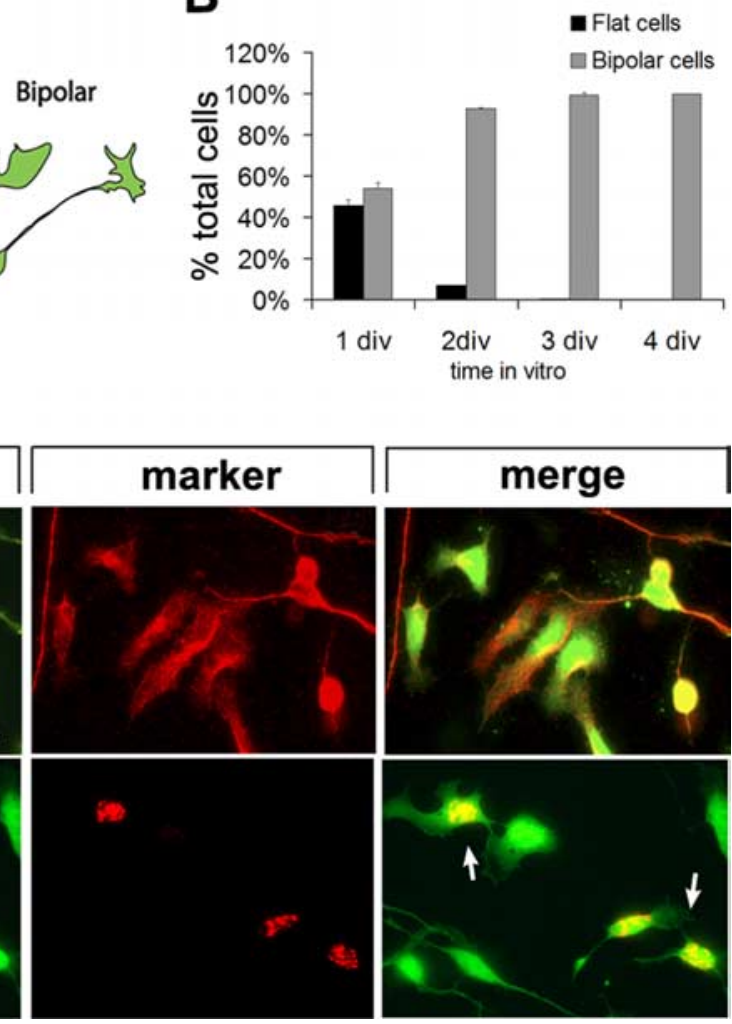

GFP
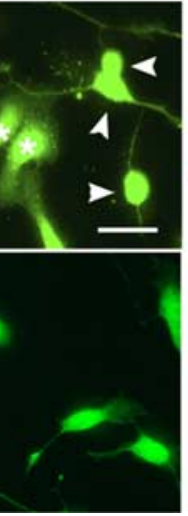

Bipolar

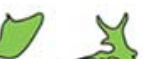

Figure 2. Freshly plated cerebellar granule neuron cultures are composed of immature, EGL-like cells. $A$, Tracings of the two morphologies observed in cultured granule cells: flat, amoeboid cells with a large nucleus and no processes; and bipolar cells. Examples of flat and bipolar cells are indicated in the top left panel in $C$ : asterisks mark flat cells and arrowheads indicate bipola independent experiments + SEM. C, Flat cells are immature, proliferating neuron progenitors. Cerebellar cells from GFP transgenic animals were fixed $1 \mathrm{~d}$ after plating and immunostained for $\beta$ Ill-tubulin and BrdU incorporation. All flat cells express the neuronal marker $\beta$ III-tubulin, like all bipolar cells. Most flat cells are positive for BrdU, indicating that they are proliferating (arrows in bottom right panel). Scale bar, $20 \mu \mathrm{m}$.

entiation marker expression, freshly plated purified granule cells represent an EGL progenitor-like population, and by 4 div, cultured granule cells can be considered IGL-like neurons.

Pontine mossy fiber outgrowth is prevented by EGL-like cells, but not by IGL-like granule neurons

Granule cell preparations and mossy fiber explants for our coculture experiments had previously been performed on the same day (Baird et al., 1992a,b; Zhang and Mason, 1998). Therefore, based on the data presented above, pontine explants in our previous studies were exposed to EGL-like granule cells. If the stop signal is expressed by immature granule neurons to prevent invasion of the EGL, then more differentiated, IGL-like granule cells on which mossy fibers ultimately terminate, would not be expected to inhibit outgrowth.

To test the effect of immature versus mature granule neurons on pontine mossy fiber growth, we developed a border-assay coculture paradigm (half-dish cultures) (Fig. 4A). Purified granule neurons harvested from wild-type pups were plated in onehalf of the dish and pontine explants were aligned in the empty space adjacent to the granule cell border. In addition, to facilitate mossy fiber identification, pontine explants were dissected from $\beta$-actin-GFP transgenic mice and cultured with wild-type granule cells. Explants were plated with EGL-like ( 0 div) or IGL-like (4 div) granule cells and cocultures were maintained for an additional 24-36 h before fixation. When explants were challenged 


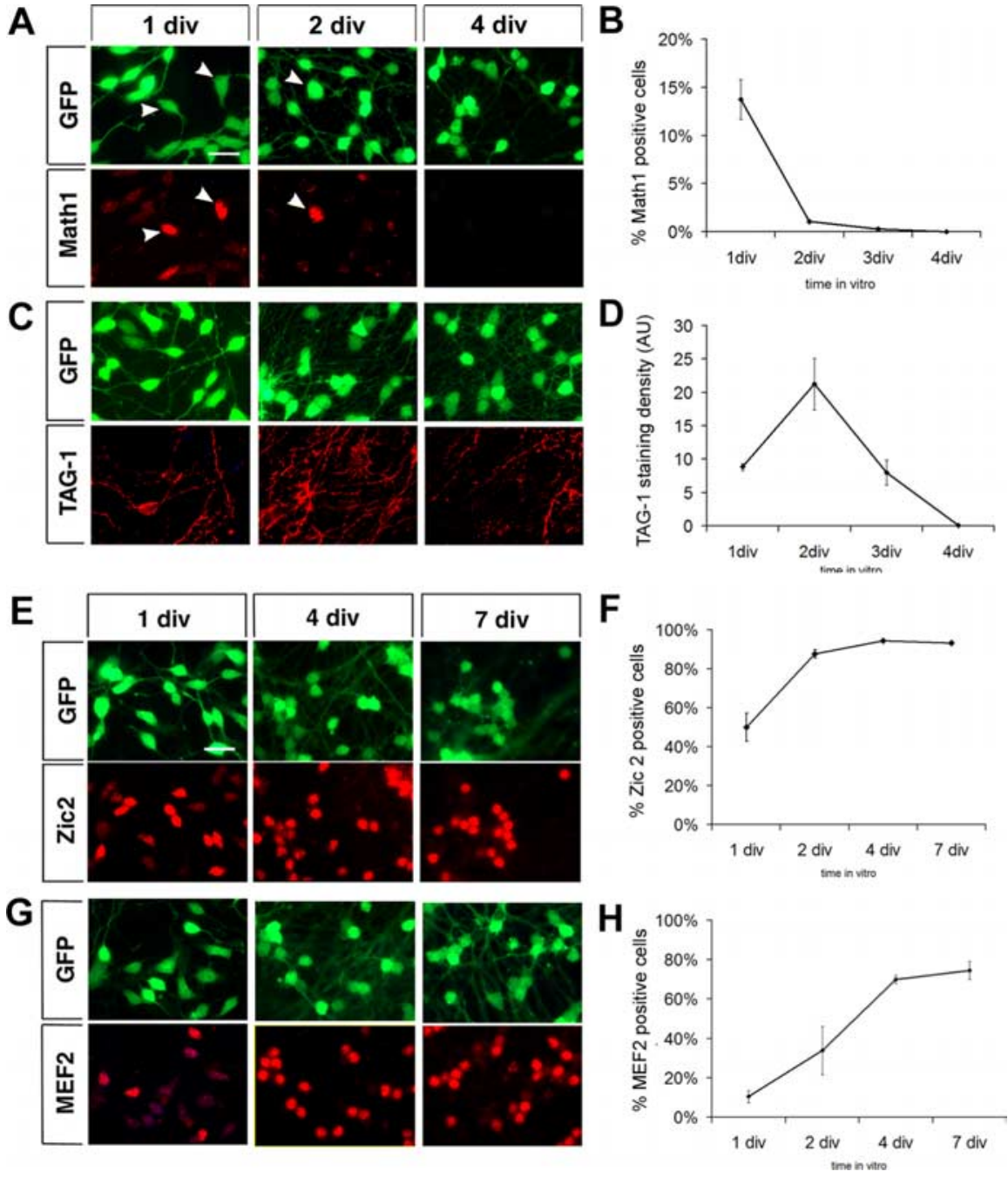

Figure 3. Granule neurons in culture transit into an IGL-like population after 4 div. $A, C, E, G$, Differentiation of cultured granule neurons is chronicled by expression of developmental stage-specific markers. Cellular morphology is visualized by GFP expression, in green, and marker staining is detected in red. Quantification of marker expression is shown in $\boldsymbol{B}, \boldsymbol{D}, \boldsymbol{F}$, and $\boldsymbol{H}$. $\boldsymbol{A}, \boldsymbol{B}, 0$ uter-EGL proliferating granule cell progenitor marker, Math1, is expressed after plating and disappears by 4 div. Math1 is exclusively expressed in flat cells (arrowheads). C, D, Premigratory and migratory granule cell marker, TAG-1, is first expressed on developing processes of bipolar cells at 1 div, peaks at 2 div, and declines thereafter. $\boldsymbol{E}, \boldsymbol{F}$, Postmitotic granule cell marker, Zic2, appears in the nuclei of postmitotic, bipolar neurons at 1 div and is expressed in all neurons by 4 div. $\boldsymbol{G}, \boldsymbol{H}$, Differentiated neuron marker MEF2 is also expressed in postmitotic neurons, but expression is delayed with respect to Zic2. Scale bars, $15 \mu \mathrm{m}$. Math1, Zic2, and MEF2 expression is represented as percentage of positive cells in three independent experiments \pm SEM. TAG-1 expression is represented as staining density (area of TAG-1 staining/number of cells in the field) in four independent experiments \pm SEM.

with EGL-like cells, axons entered only the border of the territory covered by granule neurons in $100 \%$ of explants tested ( $n$ of explants $=15 ; N$ of experiments $=3$ ) (Fig. $4 B$ ). Some axons seemed to stop growing at the border, whereas other axons were diverted and continued to grow along the border. In contrast, when granule neurons were allowed to differentiate for $4 \mathrm{~d}$ to an IGL-like population before explants were plated, mossy fibers passed over the border and grew freely on the granule cells $(n=6$; $N=3$ ) (Fig. 4C).

Outgrowth measurements in half-dish cultures are difficult because of the variability in the positioning of the explant body with respect to the granule cell border. To more reliably quantify the effects of granule neurons of different ages on mossy fiber outgrowth, coculture experiments were repeated by plating pontine explants directly on a monolayer of granule neurons (fulldish cultures) and axon length was measured in all four quad- rants. No difference was observed in pontine explant attachment between halfdish and full-dish cultures. In both types of culture, the rate of differentiation of granule neurons, as determined by expression of developmental stage-specific markers, was not altered by the presence of pontine explants in the culture (data not shown). Mossy fiber outgrowth on granule neurons at different stages of differentiation was compared with growth on a laminin substrate. Explants plated on IGL-like (4 div) cells showed growth indistinguishable from control explants grown on laminin (growth, 106.6 $\pm 9.9 \%$ of control; $n=15$; $N=3)$, whereas growth on EGL-like (0 div) neurons was reduced to $69.3 \pm 5.3 \%$ of laminin controls $(n=12 ; N=3 ; p<$ $0.001)$

The pattern of mossy fiber extension was also dramatically different on immature and mature granule neurons. After $1 \mathrm{~d}$ in coculture, axons growing on IGL-like cells (plated $4 \mathrm{~d}$ before coculture) were defasciculated and formed varicosities (Fig. $5 B$ ), whereas axons on EGL-like cells were shorter and smoother, with long filopodia, and lacked varicosities (Fig. 5A). When mossy fibers grow into the IGL in vivo, they defasciculate, branch, and form en passant synapses on several granule neurons (Mason and Gregory, 1984; Mason, 1986). We therefore asked whether the varicosities observed in IGL-like cells were nascent synaptic contacts. Synapses can be identified by immunocytochemistry by colocalization of a presynaptic vesicle marker, such as synapsin I, with a postsynaptic density scaffold marker, such as PSD-95 (Ahmari and Smith, 2002). When pontine explants were cocultured with differentiated granule neurons, synaptic vesicles were clustered in axonal varicosities in the GFP-positive mossy fibers opposed to postsynaptic PSD-95 clusters on granule neurons, reminiscent of nascent presynaptic structures (Fig. 5Bii). In contrast, PDS-95 clustering was rarely observed on immature granule cells (Fig. 5Aii), suggesting that immature granule neurons support synapse formation less well than more mature cells.

Granule cells form synapses with each other in culture (Losi et al., 2002), and synaptogenesis in purified cultures of granule cells alone increases with differentiation, with very few synapses observed in immature cultures and synaptogenesis increasing after 4 div (supplemental Fig. 1, available at www.jneurosci.org as supplemental material). It is possible that synapse formation observed in cocultures of pontine explants with mature (4 div) granule cells may simply reflect an increase in synapse formation among granule cells, rather than between pontine fibers and granule cells. To visualize synaptic contacts between mossy fibers and granule cells more clearly, we cocultured GFP-positive pontine explants with granule cells at a density of $2.5 \times 10^{4}$ cells $/ \mathrm{cm}^{2}$, a density 10 times lower than in regular cocultures. Because gran- 
ule cells do not survive well at low densities, but are still healthy after $2 \mathrm{~d}$, synapse formation was analyzed in cocultures in which both preparations were performed the same day and kept in culture for $48 \mathrm{~h}$. In this setting, mossy fiber behavior in relation to both flat (immature) and bipolar (more mature) cells could also be compared. Contacts between isolated pontine axons and isolated granule cells were identified by colocalization of the GFP-positive axons, synapsin I clusters and PSD-95 clusters. Mossy fibers avoided immature flat cells in their path and often took circuitous routes to do so (supplemental Fig. 2, available at www.jneurosci.org as supplemental material), whereas axonal contacts on granule neurons with a bipolar morphology were observed to be synaptic (Fig. $5 C$ ).

We wondered whether the stopping activity could be a collapse-inducing factor such as the semaphorins. In time-lapse video analyses in our previous studies, we never observed mossy fiber growth cone collapse during interactions with freshly plated granule cell cultures (Baird et al., 1992a). However, at the time, we were not aware of the developmental distinction between flat and bipolar granule cells in these cultures at 1-2 d in vitro. In the present work, in static analyses, we determined that mossy fiber growth cones do not exhibit collapse in the presence of EGL-like cells, but simply stop on them or grow around them (supplemental Fig. 2, available at www.jneurosci.org as supplemental material). We also never observed collapsed growth cones when mossy fiber growth cones abut the border of the EGL in vivo (Fig. $1 D$, growth cones).

In summary, whereas mossy fibers grow freely and are able to form synapses on differentiated granule cells, pontine afferents do not extend on immature EGL cells.

Proliferating, outer-EGL cells are more inhibitory to mossy fiber outgrowth than inner-EGL cells

As indicated above, mossy fiber afferents avoid growing on flat cells, the most immature of EGL cells recovered within the purified granule cell population. The EGL is composed of different populations of granule neurons precursors, proliferating progenitors in the outer-EGL, and postmitotic neurons that extend processes and initiate migration in the inner-EGL (Altman and Bayer, 1997). To test whether the inhibitory activity is enriched in outerEGL cells, we developed an immunopanning procedure to separate outer- and
A

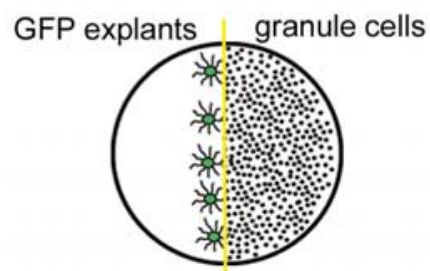

B
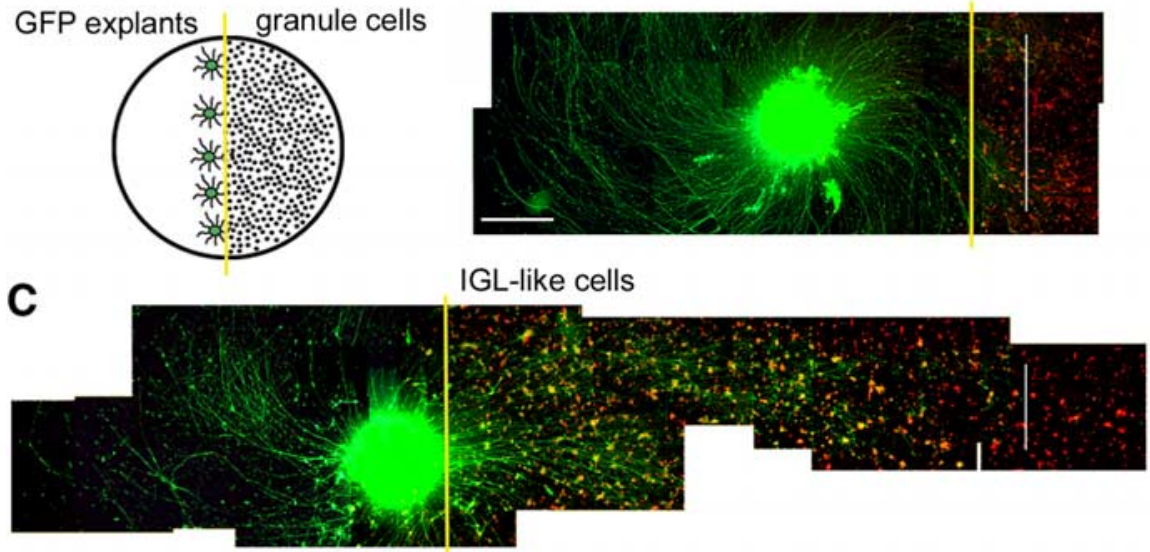

Figure 4. Immature, EGL-like granule cells inhibit mossy fiber outgrowth, whereas differentiated, IGL-like cells support unrestricted growth. $\boldsymbol{A}$, Schematic representation of the border assay. Granule neurons are plated on one-half of the dish and GFPpositive pontine explants (in green) are aligned at the border (yellow line). B, C, GFP-positive pontine explants were plated with EGL-like (0 div) $(\boldsymbol{B})$, or IGL-like (4 div) granule neurons $(\boldsymbol{C})$, and fixed after $2 \mathrm{~d}$ in culture. Granule neurons at different ages were visualized by immunostaining with a developmental marker appropriate for that age: TAG-1 in $\boldsymbol{B}$, Zic2 in $\boldsymbol{C}$. The yellow line indicates the position of the border, whereas the white line marks the farthest point of axonal extension on the granule cells. Scale bar: (in $B) B, C, 200 \mu \mathrm{m}$.
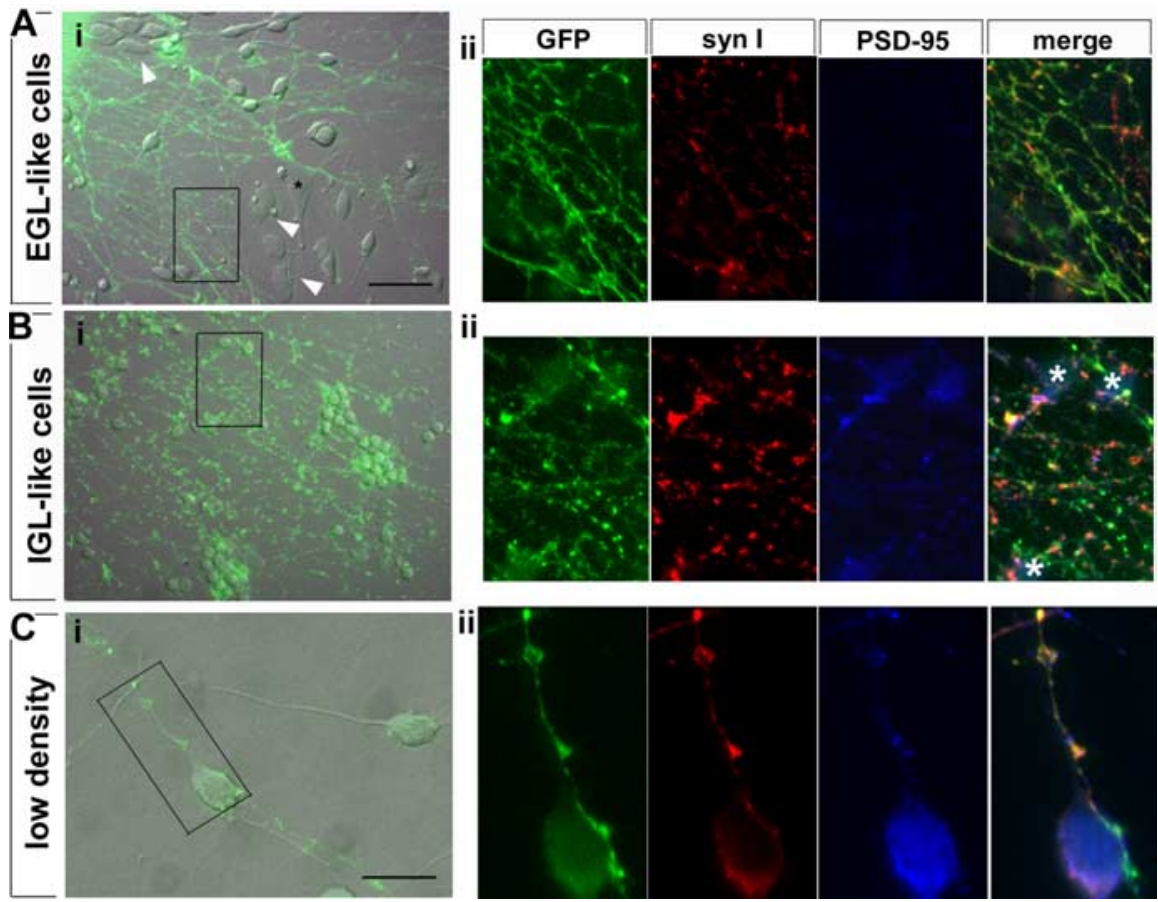

Figure 5. Pontine axons avoid immature EGL-like cells but readily extend and form synapses on IGL-like granule neurons. $\boldsymbol{A}$, Pontine axon outgrowth is fasciculated and stunted on EGL-like cells (Ai), and synapse formation is not observed (Aii). Ai, Overlay of GFP fluorescence in pontine axons with differential interference contrast image of the same field. Granule cells at different developmental stages are distinguishable as immature proliferative cells are flat (arrowheads) and postmitotic cells have smaller fusiform cell bodies. Mossy fibers avoid regions covered by flat cells but grow on more differentiated cells. Aii, Synaptic vesicle clusters, marked by synapsin I expression (syn I), are present in pontine axons on immature granule cells but are not colocalized with postsynaptic PSD-95 clusters. $\boldsymbol{B}$, Pontine axons grow extensively on IGL-like granule cells (Bi) and form synaptic varicosities (Bii). Bi, Mossy fibers are spread over cell bodies and processes of IGL-like granule neurons and form numerous enlarged GFP-positive varicosities. Bii, Mossy fiber varicosities have synaptic vesicles, and in the vicinity of granule cell bodies (white asterisks), synaptic contacts are present as indicated by colocalization (in white) of GFP (green), synapsin I (red), and PSD-95 (blue). Scale bar, $20 \mu$ m. C, Synapse formation can be clearly observed between isolated bipolar granule cells and mossy fibers. When GFP-positive pontine explants are grown on low-density granule cell cultures $(\boldsymbol{C} i)$, synaptic contacts formed by mossy fibers (green) on granule cells can be identified by colocalization of GFP with synapsin I (red) and PSD-95 (blue) (Cii). Scale bars: (in $\boldsymbol{A}$ ) $\boldsymbol{A}, \boldsymbol{B}, 40 \mu \mathrm{m}$; C, $20 \mu \mathrm{m}$. 

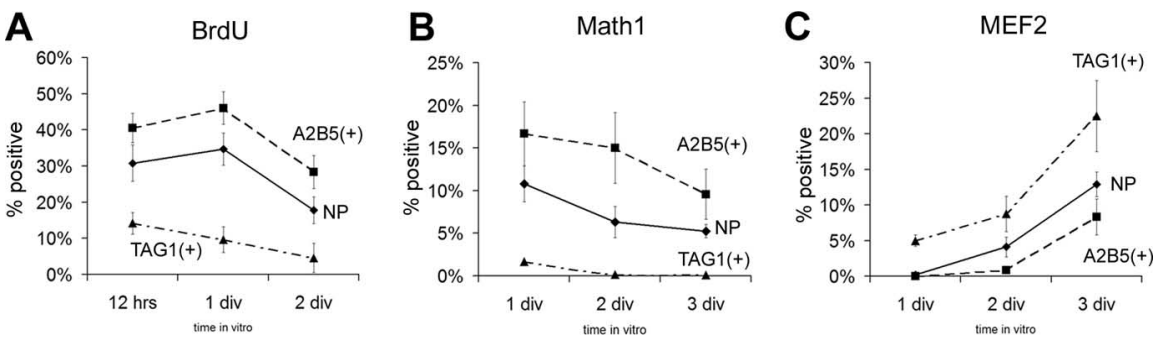

Figure 6. EGL-like granule neurons can be further purified to separate the outer A2B5( + ) and inner TAG-1(+) EGL populations. $\boldsymbol{A}-\boldsymbol{C}$, Comparison of proliferation and developmental marker expression among $\mathrm{A} 2 \mathrm{~B} 5(+), \mathrm{TAG}-1(+)$ subpopulations and nonpanned cells (NP) by quantification of BrdU incorporation ( $\boldsymbol{A})$, Math1 expression $(\boldsymbol{B})$, and MEF2 expression (C). Differentiation of the $\mathrm{A} 2 \mathrm{~B} 5(+)$ subpopulation lags behind NP cells, as $\mathrm{A2B5}(+)$ cells proliferate more and show higher Math1 and lower MEF2 expression. TAG-1(+) cells represent a more differentiated subpopulation: they show almost no proliferation, no Math1 expression, and higher MEF2 expression than NP cells. BrdU, Math1, and MEF2 expression are represented as percentage of positive cells in at least three independent experiments \pm SEM.

inner-EGL cells and to test their effect on afferent axons. After Percoll gradient purification, granule cells from wild-type $\mathrm{P} 5$ cerebella were further separated based on their surface expression of the surface ganglioside antigen A2B5, which is highly expressed on proliferating cells (Schnitzer and Schachner, 1982), or of the postmitotic, migratory neuron marker TAG-1 (Stottmann and Rivas, 1998). Cells from both populations were obtained in ratios similar to those observed in nonpanned cultures, suggesting that both types of EGL cells survive the harvesting procedure: A2B5and TAG-1-panned cells represented $55 \pm 3$ and $34 \pm 3 \%$ of the total cells used for immunopanning, respectively, and were observed in nonpanned (NP) cultures in similar proportions (52 \pm 4 and $29 \pm 5 \%$ of A2B5- and TAG-1-positive cells, identified $2 \mathrm{~h}$ after plating).

Developmental marker expression and differentiation potential were analyzed in the two panned neuronal populations, which we term A2B5 $(+)$ and TAG-1 $(+)$, and compared with NP cells. Because A2B5(+) cells represent an outer EGL population, most of these cell should be proliferative at plating and then differentiate into postmitotic, migratory cells during the second or third day in vitro. Postmitotic TAG-1(+) cells should express markers of a more differentiated migratory population and incorporate little or no BrdU, because most cells should have exited the cell cycle. As expected, A2B5(+) cells showed high BrdU incorporation $(47.2 \pm 16.0 \%)$ (Fig. 6 A), whereas TAG-1 $(+)$ cells were mostly postmitotic (BrdU positive, $8.5 \pm 6.4 \%$ ) (Fig. 6A). Expression of early (Fig. 6B, Math1) and late (Fig. 6C, MEF2) differentiation markers in A2B5 $(+)$ and TAG $(+)$ cells was compared with that of NP cells, which are a mixture of both cell subpopulations. A2B5(+) cells lagged $\sim 24 \mathrm{~h}$ behind the NP neurons in their differentiation program, whereas the TAG-1(+) population was more differentiated (Fig. $6 B, C$ ). Both A2B5(+) and TAG- $1(+)$ cells differentiated at a rate similar to that in NP neurons. Thus, by immunopanning, we purified EGL neurons into A2B5(+) cells, which represent a population of immature EGL granule neurons, and TAG-1(+) cells, which are equivalent to postmitotic migratory cells.

We then asked which of the two subpopulations of EGL cells presented a more potent stop signal. Pontine explants were cocultured on a monolayer of either A2B5 $(+)$ or TAG-1 $(+)$ granule cells in a full-dish configuration, and axon outgrowth on the two populations was compared with unrestricted outgrowth on laminin alone and on NP cells. Postmitotic, migratory TAG-1(+) cells allowed almost unrestricted growth (axon length, $80.1 \pm$ $0.5 \%$ of laminin control; $n=60 ; N=7$ ), whereas the immature
A2B5(+) population strongly inhibited mossy fiber extension (axon length, $41.6 \pm$ $1.4 \%$ of laminin control; $n=60 ; N=7$; $\left.p_{\text {contr }}<0.001 ; p_{\mathrm{NP}}<0.05\right)$ (Fig. 7). Growth on NP cells was reduced at an intermediate level between $\mathrm{A} 2 \mathrm{~B} 5(+)$ and TAG-1(+) cells, reflecting the fact that NP cells are a mixture of inner- and outerEGL cells (axon length, $59.8 \pm 3.5 \%$ of laminin control; $n=36 ; N=7 ; p_{\text {contr }}<$ $\left.0.01 ; p_{\mathrm{NP}}<0.05\right)$. Thus, immature, proliferating EGL cells and not migratory granule cells are the source of the stopping activity.

\section{Extracellular matrix components on immature granule cells arrest mossy fiber extension}

The molecular identity of the stop signal has proven to be elusive. In previous studies, conditioned medium from granule cell cultures had failed to induce pontine axon arrest (Zhang and Mason, 1998); therefore, we asked whether the stop signal could be an integral plasma membrane protein or a component of the extracellular matrix (ECM). We first tested whether plasma membranes prepared from freshly purified, immature granule cells via density-gradient centrifugation could arrest mossy fiber extension. Granule cell plasma membranes presented both in a halfdish or full-dish setting had no effect on pontine axon outgrowth compared with growth on laminin. Only when immature (0 div) granule cells were freeze-fixed on the dish before the addition of pontine explants was pontine axon extension inhibited to a similar extent as in sister dishes with live cells (extension on live immature granule cells, $66.2 \pm 1.4 \%$ of laminin control, $n=35$, $N=6, p_{\text {contr }}<0.001$; extension on freeze-fixed immature granule cells, $54.9 \pm 1.8 \%$ of laminin control, $n=35, N=6$, $p_{\text {contr }}<$ $0.001)$. Therefore, the stopping activity may be a protein loosely tethered to the plasma membrane of a component of the ECM that is lost during plasma membrane purification but preserved by freeze-fixation.

The ECM and several guidance cues that are associated with the ECM have been shown to be important regulators of axon extension and guidance at all stages of differentiation (Letourneau et al., 1992; Bovolenta and Fernaud-Espinosa, 2000). ECM components, such as proteoglycans (PGs) not only trap guidance cues and enhance binding with their receptors, but also modulate adhesive interactions directly both by favoring or inhibiting axon outgrowth (Margolis and Margolis, 1997; Bovolenta and Fernaud-Espinosa, 2000).

As a first attempt to analyze the role of ECM components in mossy fiber outgrowth, we treated granule cell/mossy fiber cocultures with heparin, which competitively inhibits binding among heparan-sulfate proteoglycans (HSPGs) or between HSPGs with other ECM components and heparin-binding proteins. Pontine explants were cocultured with granule neurons prepared the same day (EGL-like) or $4 \mathrm{~d}$ before (IGL-like). Explants were allowed to attach overnight and then treated with $10 \mu \mathrm{g} / \mathrm{ml}$ heparin for $24 \mathrm{~h}$. Heparin treatment effectively disrupted the stop signal and allowed mossy fibers to grow freely on EGL-like granule cell cultures, and interestingly, outgrowth from heparin-treated explants on immature, EGL-like granule cells was significantly more robust than growth from control explants on laminin (growth on EGL-like cells: control, $60.4 \pm 23.4 \%$ of laminin control, $n=36, N=3$; heparin treated, $164.3 \pm 11.6 \%$ of laminin 


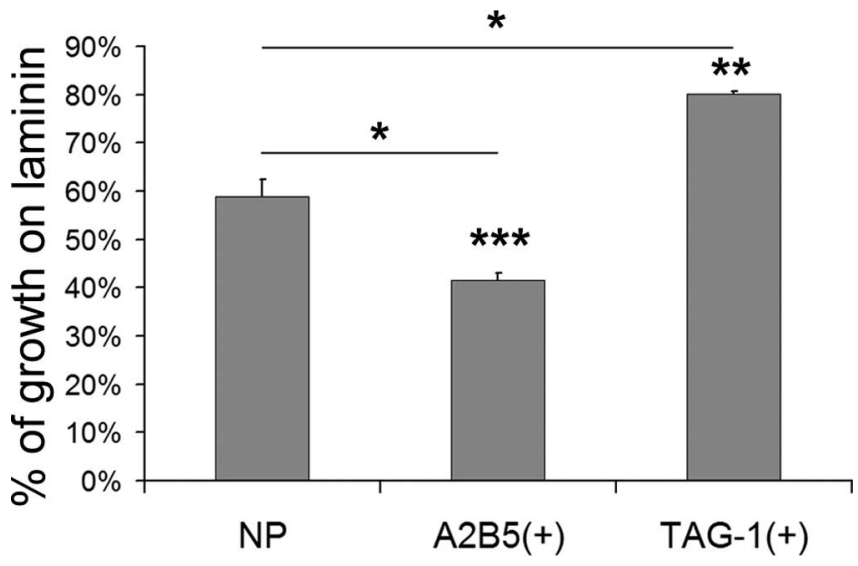

Figure 7. Immature EGL cells are the strongest source of the stop signal. $A$, Quantification of pontine explant outgrowth in full-dish cultures of NP, outer-EGL A2B5-positive $[A 2 B 5(+)]$, and inner-EGL TAG-1-positive [TAG-1(+)] cultures compared with unrestricted growth on a laminin substrate. Progenitor-like A2B5(+) cells inhibit mossy fiber outgrowth to a greater extent than NP cells, whereas postmitotic and migratory TAG- $1(+)$ cells have a smaller effect on outgrowth. ${ }^{*} p<0.05,{ }^{* *} p<0.01,{ }^{* * *} p<0.001$. Asterisks on columns indicate significance to laminin control. Error bars indicate SEM.

control, $n=29, N=3$ ) (Fig. $8 A, B$ ). Heparin did not increase pontine outgrowth per se, but it seemed to uncover a permissive signal on immature granule cells. In fact, pontine axon outgrowth on mature, IGL-like granule cells was not affected by heparin treatment (growth on IGL-like cells: control, $112.6 \pm 13.9 \%$ of laminin control, $n=29, N=3$; heparin treated, $127.4 \pm 31.6 \%$ of laminin control, $n=24, N=3$ ) (Fig. $8 A, B$ ). In addition, when heparin was applied to pontine explants in the absence of granule cells, outgrowth was reduced (heparin treated, $43.7 \pm 11.3 \%$ of laminin control; $n=31 ; N=4 ; p>0.005)$. PG-laminin complexes have been shown to be important in the regulation of axonal growth (Chiu et al., 1986; Snow et al., 2002), and heparin may block the growth-promoting interaction with the laminin substrate.

To determine whether differences in expression of PGs on granule cells could explain the differences in pontine axon outgrowth, we analyzed PG expression using biotin-conjugated WFA, a lectin which binds specifically to $N$-acetylglycosamine (Koppe et al., 1997). PGs were present on both immature (0 div) and mature (4 div) granule cells (Fig. 8C) (WFA-positive cells: $85.1 \pm 2.2 \%$ of flat cells at $0 \mathrm{div} ; 78.3 \pm 2.8 \%$ of bipolar cells at 0 div; $81.7 \pm 8.5 \%$ of granule cells at $4 \mathrm{div}$ ). No WFA binding could be detected on pontine axons at 1 or 2 div.

In summary, pontine mossy fiber arrest at the inferior border of the EGL could be controlled by a specific ECM component and/or a guidance cue with a heparin-binding domain that is exclusively expressed in the EGL.

\section{Discussion}

To form appropriate connections in the developing brain, afferent axons must navigate to the target region and recognize the correct target cells for synapse formation, while avoiding inappropriate regions and cells. Although many cues have been identified in pathways leading to target regions (Tessier-Lavigne and Goodman, 1996; Yu and Bargmann, 2001; Salie et al., 2005), the signals regulating afferent-target cell interactions within target regions are poorly defined (Holt and Harris, 1998; Sanes and Lichtman, 1999; McLaughlin et al., 2003).

From single-fiber labeling, we determined that, in late embry- onic stages and during the first postnatal week, mossy fibers leave the medial cerebellar peduncle, enter the presumptive IGL, and grow among Purkinje cells, but never enter the EGL, the layer in which their target cells are born (Mason and Gregory, 1984; present study). Mossy fibers likely encounter a series of cues that signal growth, repulsion, and synapse formation: (1) a signal allowing or inducing growth in the developing cerebellum, (2) an inhibitory signal(s) that prevent invasion of immature regions, (3) another inhibitory signal(s) from inappropriate targets such as Purkinje cells, and (4) synaptogenic signal(s) from target neurons to enable formation of presynaptic specializations on these targets. The identities of many of these signals are unknown, and to understand the mechanisms of afferent extension and differentiation, the cellular source and the timing of expression of these cues must first be elucidated.

Previous work from our laboratory indicated that cerebellar granule neurons express an inhibitory activity, termed the "stop signal," which arrested mossy fiber extension (Baird et al., 1992a,b, 1996). We proposed that the IGL-like granule neurons in the cultures arrested mossy fiber extension as a prelude to synaptogenesis (Mason et al., 1997). However, additional characterization of the composition of granule cell cultures demonstrated that only EGL neurons survive the harvesting procedure (Raetzman and Siegel, 1999), supporting the alternative hypothesis that granule cells in the EGL may express a signal to prevent mossy fibers from invading immature target cell loci.

In the present work, we characterized the interaction of pontine mossy fibers with granule cells at different developmental stages in vitro and in vivo, and found that granule cells differentially affect the behavior of their afferents depending on the stage of granule cell maturity, preventing outgrowth when in the progenitor stage, and promoting growth and synaptogenesis in the mature stage. Such behaviors reflect the activities in vivo where mossy fibers can grow through the IGL while forming synapses with mature granule and Golgi cells (Mason and Gregory, 1984; Mason, 1986), extend among and past the Purkinje cell bodies to the borders of the EGL, but never enter the EGL where immature granule cells reside. The presence of the EGL is necessary to restrict mossy fiber outgrowth, because in the agranular portions of the meander tail cerebellum, fibers extend to the pia and grow under its surface. Thus, we propose that immature granule neurons in the EGL are the cellular source of the signal that restricts mossy fiber outgrowth to the layers below, during the first postnatal week.

Neuronal progenitors have been shown to inhibit afferent invasion of immature regions in other systems. Thalamocortical projections, for example, are inhibited by both the subventricular zone, where cortical neurons are generated (Bagnard et al., 1998), and by immature layer 4 neurons (Gotz et al., 1992; Tuttle et al., 1995). When thalamocortical axons enter the developing cortex, they pause and wait below the cortical plate for their targets, layer 4 neurons, to mature before synapsing on them. In coculture experiments, immature embryonic cortical plate neurons inhibit thalamocortical axon extension, while more differentiated postnatal cortical cells support axonal growth (Gotz et al., 1992; Tuttle et al., 1995). Similarly, in the optic tectum of Xenopus laevis, the posterior tectum continues to proliferate throughout life (Straznicky and Gaze, 1972) and expresses the inhibitory cue semaphorin3A to prevent RGC axons from coming into contact with immature cells (Campbell et al., 2001).

Immature mossy fiber growth cones may also have a developmental role as they extend up into the molecular layer. They may be involved in EGL development, as shown for pioneer olfactory 


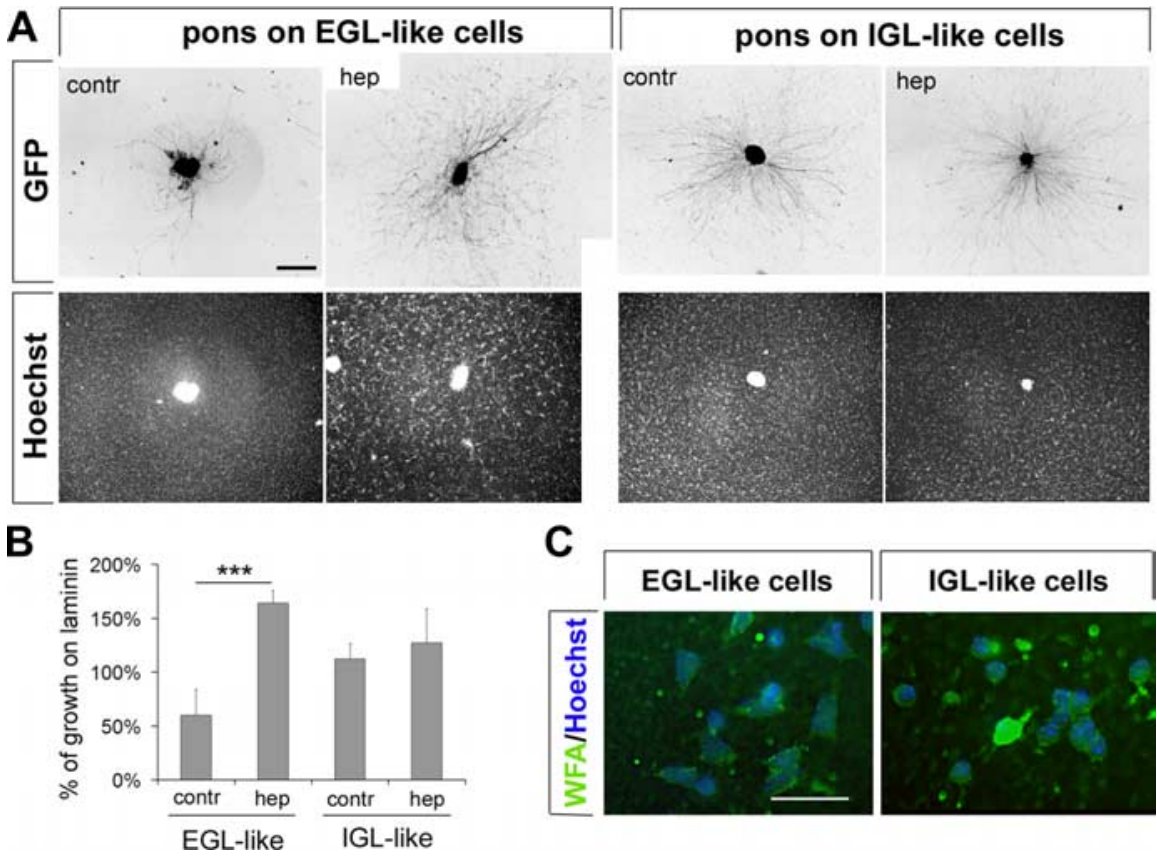

Figure 8. The stop signal is dependent on heparin binding. $\boldsymbol{A}$, Outgrowth from pontine explants is inhibited when they are plated on 0 div granule cells, but heparin (hep) treatment effectively blocks the stopping activity. No changes in outgrowth are observed when pontine explants are plated on IGL-like 4 div granule cells with heparin treatment. Top row, GFP staining to selectively label pontine explants is inverted to ease visualization of outgrowth. Bottom row, Nuclear labeling with Hoechst 33258 allows comparison of granule cell density in culture. Scale bar, $200 \mu \mathrm{m}$. contr, Control. $\boldsymbol{B}$, Quantification of pontine axon outgrowth on EGL-like and IGL-like cells with and without hep treatment compared with growth on laminin. ${ }^{* *} p<0.001$. Error bars indicate SEM. C, Proteoglycans identified by WFA staining (in green) are present in EGL-like ( 0 div) and IGL-like (4 div) granule cells. Nuclear staining with Hoechst 33258 (in blue) is used to visualize the location of the cell bodies. The large green spot in the IGL-like cell panel is a dead pyknotic cell, because dead cells tend to stain very brightly for WFA. Scale bar, $40 \mu \mathrm{m}$.

axons that induce proliferation of olfactory bulb progenitors (Gong and Shipley, 1995), or reach up to the borders of the EGL to initiate contact with migratory granule cells (Liesi et al., 2003). Some models of afferent development invoke immature, transient cells, such in the subplate (Herrmann et al., 1994), to serve as temporary way stations for growing axons before they can synapse on their targets. Both migratory granule cells and Purkinje cells could play such a role in cerebellar development. Late prenatally and early postnatally, mossy fiber afferents invade the Purkinje cell zone (Fig. 1) (Mason and Gregory, 1984) and send thin filopodial processes, "combination fibers," to both migratory granule cells and Purkinje cell bodies (Ramon y Cajal, 1911; Mason and Gregory, 1984; Liesi et al., 2003). Whether these temporary contacts are fully synaptic in nature and whether, as in the subplate, they are necessary for the normal maturation of the circuitry (Herrmann et al., 1994; Kanold et al., 2003) is currently under study (A. Kalinovsky, C. A. Mason, and P. Scheiffele, unpublished observations).

In addition to a stop-growing signal from immature granule cells, Purkinje cells may also bear a signal to prevent formation of mature synaptic contacts with mossy afferents, as previously proposed (Arsenio Nunes and Sotelo, 1985). In adult Sema6A (semaphorin6A)-deficient cerebella, mature mossy fibers synapse on ectopic granule cells stranded in the molecular layer because of migration defects (Kerjan et al., 2005). These observations in the adult suggest that when mossy fiber contacts are maintained in the molecular layer, mossy fiber afferents synapse exclusively with their appropriate granule cell targets.

The signals inhibiting, or supporting, mossy fiber outgrowth are still unknown. Several molecules important for formation of a presynaptic specializations at the mossy fiber-granule cell synapse have been identified: neuroligin (Scheiffele et al., 2000), WNT7a (Hall et al., 2000), and FGF22 (Umemori et al., 2004). Although these signals regulate synapse formation, they do not seem to affect the extent of axon outgrowth in vitro or in vivo, supporting the idea that synapse formation and stopping/pausing on specific target cells are differentially regulated. The molecules controlling mossy fiber extension in the IGL may be elusive or even nonexistent, as pontine axons grow freely on several types of neuronal and non-neuronal cells as long as the cells do not express inhibitory factors (Baird et al., 1992a; Scheiffele et al., 2000).

We found that the stopping activity expressed by immature granule cells cannot be preserved in granule cell conditioned medium or in membrane preparations, but can be blocked with heparin. These results suggest that the stop signal may be a heparin-binding guidance cue or a component of the ECM. Several proteinaceous ECM components whose interaction is disrupted by heparin, such as HSPGs and CSPGs (chondroitin-sulfate proteoglycans), are highly expressed in the EGL (Rauch et al., 1991; Smith et al., 2005) and have been shown to be regulate axon extension and guidance at all stages of neuronal differentiation in numerous brain regions (Letourneau et al., 1992; Bovolenta and Fernaud-Espinosa, 2000). PG activity depends not only on the structure of the core protein, but also on the type of monosaccharides introduced in PG polysaccharide moieties, the glycosaminoglycans (GAGs) (Bovolenta and Fernaud-Espinosa, 2000; Bulow and Hobert, 2004). Expression of the enzymes that regulate GAG molecular diversity, such as glycotransferases and sulfotransferases, is developmentally regulated in the various cerebellar layers (Inatani and Yamaguchi, 2003; Yabe et al., 2005), potentially leading to variability in PG expression and function during cerebellar differentiation. Expression of specific PGs in the EGL may mediate mossy fiber arrest directly by modulating adhesive interactions and inhibiting axon outgrowth. PGs can also trap morphogens and guidance cues such as Shh, FGFs, Wnts, Slits, and semaphorins in the ECM to locally modulate various steps of neuronal differentiation from proliferation to synapse formation (Margolis and Margolis, 1997; Bovolenta and Fernaud-Espinosa, 2000; Rubin et al., 2002; Kantor et al., 2004; Piper et al., 2006). Differential local expression and retention of inhibitory molecules in the ECM of the EGL and the IGL could regulate in mossy fiber extension, as observed during development of thalamocortical projections (Emerling and Lander, 1996).

When we analyzed interactions between mossy fiber growth cones and granule cells during time-lapse video microscopy (Baird et al., 1992a) (Q. Zhang and Mason, unpublished observations), we never observed growth cone collapse and growth cone filopodia remained highly motile, suggesting that collapseinducing cues like semaphorins and Slits are not involved. Mem- 
bers of the FGF and Wnt families, released by mature granule cells or Purkinje cells, have also been implicated as regulators of mossy fiber differentiation (Rabacchi et al., 1999; Hall et al., 2000; Umemori et al., 2004). In the future, the analysis of (1) expression of specific ECM components in the cerebellum in the first postnatal week, (2) expression of heparin-binding inhibitory guidance morphogens, including FGFs and Wnts, and (3) interactions across these two groups of molecules should facilitate the identification of signals involved in mossy fiber growth regulation during axon extension and target selection.

\section{References}

Ahmari SE, Smith SJ (2002) Knowing a nascent synapse when you see it. Neuron 34:333-336.

Altman J, Bayer SA (1997) Development of the cerebellar system: in relation to its evolution, structure and functions. New York: CRC.

Arsenio Nunes ML, Sotelo C (1985) Development of the spinocerebellar system in the postnatal rat. J Comp Neurol 237:291-306.

Arsenio Nunes ML, Sotelo C, Wehrle R (1988) Organization of spinocerebellar projection map in three types of agranular cerebellum: Purkinje cells vs. granule cells as organizer element. J Comp Neurol 273:120-136.

Aruga J, Nagai T, Tokuyama T, Hayashizaki Y, Okazaki Y, Chapman VM, Mikoshiba K (1996) The mouse zic gene family. Homologues of the Drosophila pair-rule gene odd-paired. J Biol Chem 271:1043-1047.

Bagnard D, Lohrum M, Uziel D, Puschel AW, Bolz J (1998) Semaphorins act as attractive and repulsive guidance signals during the development of cortical projections. Development 125:5043-5053.

Baird DH, Hatten ME, Mason CA (1992a) Cerebellar target neurons provide a stop signal for afferent neurite extension in vitro. J Neurosci 12:619-634.

Baird DH, Baptista CA, Wang LC, Mason CA (1992b) Specificity of a target cell-derived stop signal for afferent axonal growth. J Neurobiol 23:579-591.

Baird DH, Trenkner E, Mason CA (1996) Arrest of afferent axon extension by target neurons in vitro is regulated by the NMDA receptor. J Neurosci 16:2642-2648.

Borghesani PR, Peyrin JM, Klein R, Rubin J, Carter AR, Schwartz PM, Luster A, Corfas G, Segal RA (2002) BDNF stimulates migration of cerebellar granule cells. Development 129:1435-1442.

Bovolenta P, Fernaud-Espinosa I (2000) Nervous system proteoglycans as modulators of neurite outgrowth. Prog Neurobiol 61:113-132.

Bulow HE, Hobert O (2004) Differential sulfations and epimerization define heparan sulfate specificity in nervous system development. Neuron 41:723-736.

Campbell DS, Regan AG, Lopez JS, Tannahill D, Harris WA, Holt CE (2001) Semaphorin $3 \mathrm{~A}$ elicits stage-dependent collapse, turning, and branching in Xenopus retinal growth cones. J Neurosci 21:8538-8547.

Chiu AY, Matthew WD, Patterson PH (1986) A monoclonal antibody that blocks the activity of a neurite regeneration-promoting factor: studies on the binding site and its localization in vivo. J Cell Biol 103:1383-1398.

Diaz E, Ge Y, Yang YH, Loh KC, Serafini TA, Okazaki Y, Hayashizaki Y, Speed TP, Ngai J, Scheiffele P (2002) Molecular analysis of gene expression in the developing pontocerebellar projection system. Neuron 36:417-434.

Eisenman LM, Arlinghaus LE (1991) Spinocerebellar projection in the meander tail mutant mouse: organization in the granular posterior lobe and the agranular anterior lobe. Brain Res 558:149-152.

Emerling DE, Lander AD (1996) Inhibitors and promoters of thalamic neuron adhesion and outgrowth in embryonic neocortex: functional association with chondroitin sulfate. Neuron 17:1089-1100.

Gasser UE, Hatten ME (1990) Central nervous system neurons migrate on astroglial fibers from heterotypic brain regions in vitro. Proc Natl Acad Sci USA 87:4543-4547.

Godement P, Vanselow J, Thanos S, Bonhoeffer F (1987) A study in developing visual systems with a new method of staining neurones and their processes in fixed tissue. Development 101:697-713.

Goldowitz D, Hamre K (1998) The cells and molecules that make a cerebellum. Trends Neurosci 21:375-382.

Gong Q, Shipley MT (1995) Evidence that pioneer olfactory axons regulate telencephalon cell cycle kinetics to induce the formation of the olfactory bulb. Neuron 14:91-101.

Gotz M, Novak N, Bastmeyer M, Bolz J (1992) Membrane-bound mole- cules in rat cerebral cortex regulate thalamic innervation. Development 116:507-519.

Hall AC, Lucas FR, Salinas PC (2000) Axonal remodeling and synaptic differentiation in the cerebellum is regulated by WNT-7a signaling. Cell 100:525-535.

Hamre KM, Goldowitz D (1997) meander tail acts intrinsic to granule cell precursors to disrupt cerebellar development: analysis of meander tail chimeric mice. Development 124:4201-4212.

Hatten ME (1985) Neuronal regulation of astroglial morphology and proliferation in vitro. J Cell Biol 100:384-396.

Hatten ME, Heintz N (1995) Mechanisms of neural patterning and specification in the developing cerebellum. Annu Rev Neurosci 18:385-408.

Hatten ME, Gao W-Q, Morrison ME, Mason CA (1998) The cerebellum: purification and coculture of identified cell populations. In: Culturing nerve cells, pp 419-459. Cambridge, MA: MIT.

Helms AW, Johnson JE (1998) Progenitors of dorsal commissural interneurons are defined by MATH1 expression. Development 125:919-928.

Herrmann K, Antonini A, Shatz CJ (1994) Ultrastructural evidence for synaptic interactions between thalamocortical axons and subplate neurons. Eur J Neurosci 6:1729-1742.

Holt CE, Harris WA (1998) Target selection: invasion, mapping and cell choice. Curr Opin Neurobiol 8:98-105.

Inatani M, Yamaguchi Y (2003) Gene expression of EXT1 and EXT2 during mouse brain development. Brain Res Dev Brain Res 141:129-136.

Jande SS, Maler L, Lawson DE (1981) Immunohistochemical mapping of vitamin D-dependent calcium-binding protein in brain. Nature 294:765-767.

Kanold PO, Kara P, Reid RC, Shatz CJ (2003) Role of subplate neurons in functional maturation of visual cortical columns. Science 301:521-525.

Kantor DB, Chivatakarn O, Peer KL, Oster SF, Inatani M, Hansen MJ, Flanagan JG, Yamaguchi Y, Sretavan DW, Giger RJ, Kolodkin AL (2004) Semaphorin $5 \mathrm{~A}$ is a bifunctional axon guidance cue regulated by heparan and chondroitin sulfate proteoglycans. Neuron 44:961-975.

Kerjan G, Dolan J, Haumaitre C, Schneider-Maunoury S, Fujisawa H, Mitchell KJ, Chedotal A (2005) The transmembrane semaphorin Sema6A controls cerebellar granule cell migration. Nat Neurosci 8:1516-1524.

Koppe G, Bruckner G, Brauer K, Hartig W, Bigl V (1997) Developmental patterns of proteoglycan-containing extracellular matrix in perineuronal nets and neuropil of the postnatal rat brain. Cell Tissue Res 288:33-41.

Letourneau PC, Condic ML, Snow DM (1992) Extracellular matrix and neurite outgrowth. Curr Opin Gen Dev 2:625-634.

Levine JM, Stallcup WB (1987) Plasticity of developing cerebellar cells in vitro studied with antibodies against the NG2 antigen. J Neurosci 7:2721-2731.

Liesi P, Akinshola E, Matsuba K, Lange K, Morest K (2003) Cellular migration in the postnatal rat cerebellar cortex: confocal-infrared microscopy and the rapid Golgi method. J Neurosci Res 72:290-302.

Losi G, Prybylowski K, Fu Z, Luo JH, Vicini S (2002) Silent synapses in developing cerebellar granule neurons. J Neurophysiol 87:1263-1270.

Lyons GE, Micales BK, Schwarz J, Martin JF, Olson EN (1995) Expression of mef2 genes in the mouse central nervous system suggests a role in neuronal maturation. J Neurosci 15:5727-5738.

Mao Z, Bonni A, Xia F, Nadal-Vicens M, Greenberg ME (1999) Neuronal activity-dependent cell survival mediated by transcription factor MEF2. Science 286:785-790.

Marcus RC, Blazeski R, Godement P, Mason CA (1995) Retinal axon divergence in the optic chiasm: uncrossed axons diverge from crossed axons within a midline glial specialization. J Neurosci 15:3716-3729.

Margolis RU, Margolis RK (1997) Chondroitin sulfate proteoglycans as mediators of axon growth and pathfinding. Cell Tissue Res 290:343-348.

Mason CA (1986) Axon development in mouse cerebellum: embryonic axon forms and expression of synapsin I. Neuroscience 19:1319-1333.

Mason CA, Gregory E (1984) Postnatal maturation of cerebellar mossy and climbing fibers: transient expression of dual features on single axons. J Neurosci 4:1715-1735.

Mason CA, Morrison ME, Ward MS, Zhang Q, Baird DH (1997) Axontarget interactions in the developing cerebellum. Persp Dev Neurobiol $5: 69-82$.

McLaughlin T, Hindges R, O’Leary DD (2003) Regulation of axial patterning of the retina and its topographic mapping in the brain. Curr Opin Neurobiol 13:57-69.

Okabe M, Ikawa M, Kominami K, Nakanishi T, Nishimune Y (1997) 
"Green mice" as a source of ubiquitous green cells. FEBS Lett 407:313-319.

Piper M, Anderson R, Dwivedy A, Weinl C, van Horck F, Leung KM, Cogill E, Holt C (2006) Signaling mechanisms underlying Slit2-induced collapse of Xenopus retinal growth cones. Neuron 49:215-228.

Powell SK, Rivas RJ, Rodriguez-Boulan E, Hatten ME (1997) Development of polarity in cerebellar granule neurons. J Neurobiol 32:223-236.

Rabacchi SA, Solowska JM, Kruk B, Luo Y, Raper JA, Baird DH (1999) Collapsin-1/semaphorin-III/D is regulated developmentally in Purkinje cells and collapses pontocerebellar mossy fiber neuronal growth cones. J Neurosci 19:4437-4448.

Raetzman LT, Siegel RE (1999) Immature granule neurons from cerebella of different ages exhibit distinct developmental potentials. J Neurobiol 38:559-570.

Ramon y Cajal S (1911) Histologie du système nerveux de l'homme et des vertébrés. Paris: A. Maloine.

Rauch U, Gao P, Janetzko A, Flaccus A, Hilgenberg L, Tekotte H, Margolis RK, Margolis RU (1991) Isolation and characterization of developmentally regulated chondroitin sulfate and chondroitin/keratan sulfate proteoglycans of brain identified with monoclonal antibodies. J Biol Chem 266:14785-14801.

Ross ME, Fletcher C, Mason CA, Hatten ME, Heintz N (1990) Meander tail reveals a discrete developmental unit in the mouse cerebellum. Proc Natl Acad Sci USA 87:4189-4192.

Rubin JB, Choi Y, Segal RA (2002) Cerebellar proteoglycans regulate sonic hedgehog responses during development. Development 129:2223-2232.

Salie R, Niederkofler V, Arber S (2005) Patterning molecules; multitasking in the nervous system. Neuron 45:189-192.

Sanes JR, Lichtman JW (1999) Development of the vertebrate neuromuscular junction. Annu Rev Neurosci 22:389-442.

Scheiffele P, Fan J, Choih J, Fetter R, Serafini T (2000) Neuroligin expressed in nonneuronal cells triggers presynaptic development in contacting axons. Cell 101:657-669.

Schnitzer J, Schachner M (1982) Cell type specificity of a neural cell surface antigen recognized by the monoclonal antibody A2B5. Cell Tissue Res 224:625-636.
Smith FI, Qu Q, Hong SJ, Kim KS, Gilmartin TJ, Head SR (2005) Gene expression profiling of mouse postnatal cerebellar development using oligonucleotide microarrays designed to detect differences in glycoconjugate expression. Gene Expr Patterns 5:740-749.

Snow DM, Smith JD, Gurwell JA (2002) Binding characteristics of chondroitin sulfate proteoglycans and laminin-1, and correlative neurite outgrowth behaviors in a standard tissue culture choice assay. J Neurobiol 51:285-301.

Solecki DJ, Liu XL, Tomoda T, Fang Y, Hatten ME (2001) Activated Notch2 signaling inhibits differentiation of cerebellar granule neuron precursors by maintaining proliferation. Neuron 31:557-568.

Stottmann RW, Rivas RJ (1998) Distribution of TAG-1 and synaptophysin in the developing cerebellar cortex: relationship to Purkinje cell dendritic development. J Comp Neurol 395:121-135.

Straznicky K, Gaze RM (1972) The development of the tectum in Xenopus laevis: an autoradiographic study. J Embryol Exp Morphol 28:87-115.

Tessier-Lavigne M, Goodman CS (1996) The molecular biology of axon guidance. Science 274:1123-1133.

Tuttle R, Schlaggar BL, Braisted JE, O’Leary DD (1995) Maturationdependent upregulation of growth-promoting molecules in developing cortical plate controls thalamic and cortical neurite growth. J Neurosci 15:3039-3052.

Umemori H, Linhoff MW, Ornitz DM, Sanes JR (2004) FGF22 and its close relatives are presynaptic organizing molecules in the mammalian brain. Cell 118:257-270.

Wang VY, Zoghbi HY (2001) Genetic regulation of cerebellar development. Nat Rev Neurosci 2:484-491.

Yabe T, Hata T, He J, Maeda N (2005) Developmental and regional expression of heparan sulfate sulfotransferase genes in the mouse brain. Glycobiology 15:982-993.

Yu TW, Bargmann CI (2001) Dynamic regulation of axon guidance. Nat Neurosci [Suppl]4:1169-1176.

Zhang Q, Mason CA (1998) Developmental regulation of mossy fiber afferent interactions with target granule cells. Dev Biol 195:75-87. 